$\xi=-1$

\title{
Prevention and Correction of Motivation for Illegal Behavior of Minors
}

\author{
I.Yu. Blyasova ${ }^{1}$, Yu.A. Klayberg ${ }^{2}$, Yu.A. Malyushina ${ }^{3}$, N.A. Kokanov ${ }^{4}$, T.Yu. Lushnikova ${ }^{5}$ \\ ${ }^{I}$ Department of History and Law of the Shadrinsk State Pedagogical University (Federal State-Funded Educational Institution of Higher \\ Education Shadrinsk State Pedagogical University), Russia \\ ${ }^{2}$ Moscow State Regional University, Russia \\ ${ }^{3}$ Department of General and Social Psychology at the "Kurgan State University", Russia \\ ${ }^{4}$ Institute for Advanced Studies and Retraining of Personnel of the Chelyabinsk State University (Federal State-Funded Educational \\ Institution of Higher Education Chelyabinsk State University), Russia \\ ${ }^{5}$ Department of "Economic and Legal Fundamentals of Management", Faculty of Management, Chelyabinsk State University (Federal \\ State-Funded Educational Institution of Higher Education Chelyabinsk State University), Russia \\ *Corresponding author E-mail: blyasovai@bk.ru
}

\begin{abstract}
The relevance of the research based on the necessity of studying the components of criminal motivation of minors and their psychological content.

In this regard, this article is aimed at identifying the components of criminal motivation, prevention and correction with the help of a correctional-developing training program "Quartet".

The leading approaches (or methods) of the study of this problem are the systematic approach, methods of mathematical statistics, which allows to develop and carry out prevention and correction of criminal motivation.

The article presents the results of the trainings with minors, the main concepts of criminal motivation are revealed.

The analysis of the differences between the parameters of the psychological content of the components of the motivational sphere of the personality of the juvenile offender (individual, personal, cognitive, emotional and behavioral) of the U. Student's t-criterion showed that there are reliable positive changes in the structure of the motivational sphere of the personality of the minor offender. In the control group of minors, there was no change, according to it, we can conclude that the motivation for illegal behavior of minors can be corrected by means of socio-psychological training through awareness and influence on the psychological content of the components of the structure of the motivational sphere and changes in the hierarchy of leading motives.

The materials of the article are of practical value. Research materials can be used in professional activities of investigators, juvenile inspectors, social rehabilitation centers dealing with juvenile offenders. They are applicable in dealing with educators, psychologists, and employees of law enforcement agencies for advisory and educational purposes. The technique "Dominant criminal motive" can be used both in individual work with juvenile offenders and for monitoring the state of juvenile delinquency.

The correctional-developing training program "Quartet" developed by the author can be used to change the motivational sphere of the personality of juvenile offenders, the formation of adequate behavior of minors, and to carry out measures to prevent the relapses committed by minors.

The reliability of the research results, its conclusions and recommendations is provided by the methodology and logic of the research.
\end{abstract}

Keywords: Correction, criminal motivation, minors, behavior, crime, prevention, relapse.

\section{Introduction}

The transformations taking place in various spheres of life of our society are reflected in the behavior and indicators of juvenile delinquency. In this regard, an urgent problem is the identification of internal determinants that cause criminal behavior, an analysis of the psychological structure of the motivational sphere of the offender's personality and timely and comprehensive preventive work.

The problem of deviant behavior is considered both in the psychological-pedagogical and in the legal scientific literature. The basis for the prevention of deviant behavior is the psychological theories of normal and abnormal personality development (B.G. Ananiev, L.I.Bozhovich, B.S.Bratus,
A.N.Leontiev, A.E.Licko, A. Maslow, G. Allport, K. Rogers, and others), that interpret the criminals'perceptions of generally accepted norms of behavior by means of the presence of certain values characteristic of them and which oppose the norms of social behavior. Different strategies of behavior are considered in the works of A. Bandura, L. Berkovits, D. Dollard, N. Miller, and others. The determinants of the deviant behavior of adolescents and young people are considered in the works of M.A. Alemaskin, S.A. Belichevoy, K.E.Igoshev, Yu.A. Kleiberga, I.S. Kona, V.N. Kudryavtseva, R.V.Ovcharova, A.E. Lichko, A.V. Mudrick and others). The questions of the influence of relations in the family on the development of the personality of the child were investigated by B.N. Almazov, Yu.M. Antonyan, M.I. Buyanov, A.I. Zakharov, E.I. Holostov and other [1, 4, 9, 10, 11, 15]. 
The preventive measures wasdeveloped by A. Bandura, I.P Bashkatov, A.A. Refugees, I.Yu. Blyasova, S.V. Bykov, E.L. Vinogradova, I.S. Ganishina,

E.V. Zmanovskaya, A.I. Kochetov, R. Merton, R. Johnson, E. Durkheim,

Tishchenko, R. Walters, V. Frankl and others.

The process of development of the motive of the crime and implementation of criminal acts was studied by V.L. Vasilyev, Ya.I. Gilinsky, A.I. Gorkova, V.N. Kudryavtsev, V.D. Mendelevich, G.G. Shikhantsov [18, 19].

In the foreign scientific literature, certain correlations between delinquent behavior and pedagogical neglect are revealed (B.Garson, J.West, A.E. Kazdin, P.J. Frick, Friday Paul C., H Hekkhauzen., Xin Ren Elmar G.M., Potter C.C.) [28].

In Russian science this issue is discussed in scientific studies by N.G. Magradze, T.Sh. Anguladze, I.A.Furmanov, I.P. Bashkatova, D.Z. Ziyadova, E.V. Zmanovskaya and others.

Psychological and criminological research indicates that motivation as a psychic phenomenon is interpreted in different ways. In one case it is a set of factors that support and determine behavior (K. Madsen, J.Godfroi). In the other case it is a set of motives (K.K.Platonov). In the third case, it is an incentive that induces the activity of the personality and determines its direction $[8,17,26,27]$.

All definitions of motivation can be attributed to two main directions. The first direction considers it from structural positions as a set of factors or motives

$[2,22]$ According to V.D.Shadrikov, the motivation is conditioned by the personal goals, the level of claims and ideals, the conditions of activity both objective or external, and subjective or internal knowledge, skills, abilities, character, worldview, beliefs. Taking into account these factors, a decision is taken, the intention is formed [13].

The second direction considers motivation as a dynamic formation, as a process and mechanism. In this case, motivation is a means of realizing motives that are already exist, as a means of meeting the needs. After the actual need of the individual choices the model of behavior, we can speak about the occurrence of the motive [5, 7].

Motivation of criminal behavior is understood as one of the most important elements, the identification and study of it allows to understand the reasons for this behavior and the personality of the offender better, to determine the most effective ways of its correction, and outline and implement crime prevention measures $[2,12,14]$

Characterizing the motivation for illegal behavior of minors, most researchers use terms: antisocial directions (T.Sh. Anguladze, K.Bartol.), antisocial motivation (R.E. Igoshev, D.I. Feldstein, E.V. Zmanovskaya, E.P. Ilyin, V.V. Luneev), asocialcriminal motivation(I.P. Bashkatov, I.A. Vasil'ev, ), criminal motivation (A.G.Kovalev, V.N.Kudryavtsev) $[3,6,16]$.

On the basis of theoretical and empirical research, D.S Pastushenyacomes to the conclusion that the central unit in the psychological mechanism of the criminal behavior of minors is the acceptance of a criminal purpose by the subject and the formation of criminal motivation [21].

In the study of E.M. Pavlik it was revealed that the motivational sphere of minors with different directions of committed offenses has certain differences and can be characterized by the increase of such needs as the need for security, getting adrenaline, emotionality [22]. The motivation sphere of violent criminals can be characterized by various affiliation tendencies; the predominance and presence of frustrations of material needs, the desire for self-affirmation $[23,20]$.

The foregoing demonstrates the importance of conducting timely comprehensive prevention and corrective work to prevent criminal behavior of minors.

In this system, there is a need for interrelation and interaction of different subjects of prevention.

Preventive activity is considered by the authors as an interaction of psychological, pedagogical, socio-economic, organizational and legal measures. This set of measures is aimed at neutralizing the impact of negative factors on the adolescent's personality in order to reduce and eliminate the causes and conditions of crime, and to correct the behavior of adolescent [24].

At the same time, we believe that the pedagogization of the surroundings should become the basis of modern prevention. L.I. Malenkov identifies a number of blocks in the system of preventing juvenile delinquency: the formation of the pedagogical culture at home, in family, at school; organization of the education of adolescents in the team; the organization and adoption of informal groups in the positive direction of their energy; the organization of children's and social movements with the participation of "neglected" adolescents; use of various organizational forms; use of five points of rest of education: nature, culture, activity (which a person does), people (with whom he enters into a variety of relationships), "I myself" as the highest value. Such an organization for the prevention of teenage offenses, according to the scientist, can be effective if the following conditions are met: for the adolescent education should be a chain of various predictable and unexpected events that have significant personal meaning for him and for the teacher; the basis is the pedagogical position of the teacher [4].

In the prevention of deformation of the motivational sphere, we can single out a number of directions: the timely detection of adolescents with behavioral deviations; study of the causes and conditions of occurrence of these deviations; the identification of educational opportunities to impact on adolescents of the "risk group"; planning of work on the basis of diagnosis and forecasting (identification ofaims, content, forms and methods of psychological and pedagogical influence); organization of activities to prevent deviant behavior of adolescents, monitoring the results of the preventive work; interconnection of educational institutions, family and the public $[25,5]$.

Thus, in the problem field, the role of motivation in the genesis of criminal behavior of minors, its separate parameters (needs, orientations, etc.)were considered, but the motivational sphere of juvenile offenders as a holistic integral personality formation, consisting of interrelated and interdependent components, was investigated not fully. The question of the psychological structure of the motivational sphere of the personality of juvenile delinquents and the peculiarities of the criminal motivation of crimes is little-studied; the ways of correcting criminal motivation have not been developed.

Accordingly, the problem is the lack of a well-developed concept of the motivational sphere of juvenile delinquents as a holistic psychological phenomenon and the lack of developed system for preventing motivation for the illegal behavior of minors.

\subsection{Research hypothesis}

The motivation for illegal behavior of minors can be corrected by using the means of socio-psychological training, by understanding the psychological content of the components of the structure of the motivational sphere and changing the hierarchy of the basic motives.

\subsection{Methodological basis of the research}

The study is based on the principles of the system-activity approach (V.A. Gansen, B.F. Lomov, A.N. Leontiev, S.L. Rubinstein), determinism (A.G. Asmolov, S.L. Rubinshtein); principles of legal psychology (A.M. Stolyarenko); on deviantological approaches (Ya. I. Gilinsky, Yu.A. Kleiberg, Yu.Yu. Komlev, T.A. Khagurov). The study was based on the fundamental theoretical principles and methods of legal psychology (V.L. Vasiliev, M.I. Enikeev, M.M. Kochenov, M.I. Maryin, A.R. Ratinov, O.D. Sitkovskaya, A.M. Stolyarenko, L.B. Filonov, Yu.V. Chufarovsky, G.G. Shikhantsov), the theories of criminology (N.F.Kuznetsov), revealing the determination of juvenile crimes, the interdisciplinary links of psychology and criminal law, the criminal process, criminology. 
According to the foregoing, it can be concluded that the criminal motivation of minors is a dynamic process, because it is closely related to all elements of criminal behavior. The teenager's problem that has arisen is gradually updated, then objectification of the need takes place and in the long run the criminal motive is formed.

\section{Materials and Methods}

The purpose of this part is to assess the reliability of the methods used and their effect on the results.

To achieve the goal and confirm the hypothesis put forward, in the framework of the dissertation research we conducted a study of minors in the number of 540 people. The sample size by sex: 210 girls (38.9\%) and 330 boys (61.1\%). The composition of the sample by age: $14-17$ years.

The sample is presented taking into account the subjective incentives of criminal behavior and its motives, according to the classification of Yu.M. Antonyan [1]: minors suspected of committing violent, mercenary-violent and mercenary crimes. The study was carried out with the help of the following psychodiagnostic methods: "Value orientations" by M. Rokich; "Profile of feelings in relationships" L. Kulikova; "Diagnosis of the motivational structure of the personality" V.E. Milman "Subjective evaluation of interpersonal relations" Dukhnovsky; "Questionnaire of interpersonal relations" V. Schutz; "Indicator of coping strategies" D. Amirkhan; "Index of the life style" of Plutchik-Kellerman-Conte; Projective TAT (Thematic Apperceptive Test); method of motivational induction (MIM) J. Nutten; author's technique of Yu.A. Malyushina "Dominant criminal motive" (DCM), and psychological participant observation of the behavior of minors, their relationships during the investigation, methods of mathematical statistics (Student's ttest).

\section{Results}

5 trainings were conducted to approve the program, in which 75 people (50 boys and 25 girls) took part. The average age of participants is 16.5 years. Subjects underwent preliminary diagnosis for the study of the psychological content of the cognitive, emotional, needing and behavioral components of the motivational sphere of the personality of a minor offender.

According to the above theoretical and methodological prerequisites, the theoretical model of the structure of the motivational sphere of the personality includes four blocks (Fig. $1)$.

Having determined the theoretical model and confirmed it empirically, a correction-developing training program "Quartet" (author - Y.A. Malyushina) was developed.

Target group: the training is intended for juvenile offenders at the age of 14-17 years.

Program structure: the training includes four modules of classes, which were revealed during the theoretical and empirical analysis: "Cognitive" (5 classes, including organizational), "Emotional", "Individual-personal" (5 sessions), "Behavioral" (5 sessions, including the final one).

The goal was achieved through theoretical and empirical data on the interconnections of components, and knowledge of the conten of the structure of criminal motivation.

Procedural characteristics of the training. The training program is designed for 40 academic hours, distributed for 20 lessons. Classes are held 2 times a week. The break between meetings allows the juvenile offender to comprehend the knowledge, skills and apply them in various life situations.

The work of the group in the framework of the proposed program is built in accordance with the general principles of group work (M.R. Bityanova, A.G. Liders, A.S. Spivakovskaya, K. Fopel and others).

The program and content of the training are a synthetic author's work, which combines the elements of personal growth trainings (A.G. Liders, M.Yu. Savchenko, L.A.Petrovskaya), psychological exercises (A.N. Alekseeva, V.Yu.Bolshakov, skazkoterapiya V.I.Vachkov), and our own author's exercises.

Methodical methods: role games, discussion, psycho-technical exercises, relaxation exercises.

At the end of the whole training, interviews were conducted with each participant in order to find out the general impressions of the work, to know how much their expectations coincided with the real results.

The effectiveness of the program was determined using the following criteria: "Value orientations", "Interpersonal relations", "Components of the structure of motivation", "Feelings".

Exercises of the first block (cognitive) are aimed at comprehending the essence of criminal behavior by minors, their negative consequences, legal awareness. In the process of awareness, a special role belongs to the verbalization, during it differentiation and change of personal senses of life experience of minors, acquaintance of participants with different ways of regulation of their emotional state, development of methods for restoring emotional balance occur.

Programs of work on the emotional block have also been developed. Correction of behavior, changes in the psychological components of the behavioral component, impact on the individual and personal characteristics of juvenile offenders.

All classes include a set of tasks and exercises: exercises to increase efficiency, group discussion, relaxation exercises, which are a prerequisite for active and productive work.

The control group consisted of 75 people ( 50 boys and 25 girls), selected from the total number of subjects on grounds identical to the participants in the experimental group. The control group was formed using a pair selection strategy. In the control group, training was not conducted. In the experimental group, the average level of values was measured in terms of the effectiveness of the program (before and after the training classes) to study the level of expression of indicators on the parameters of motivation for illegal behavior.

Using the Student's t-test for coupled samples, the results of two measurements conducted in the experimental group were compared (before and after the experimental action).

We turn to the discussion of the results of the study.

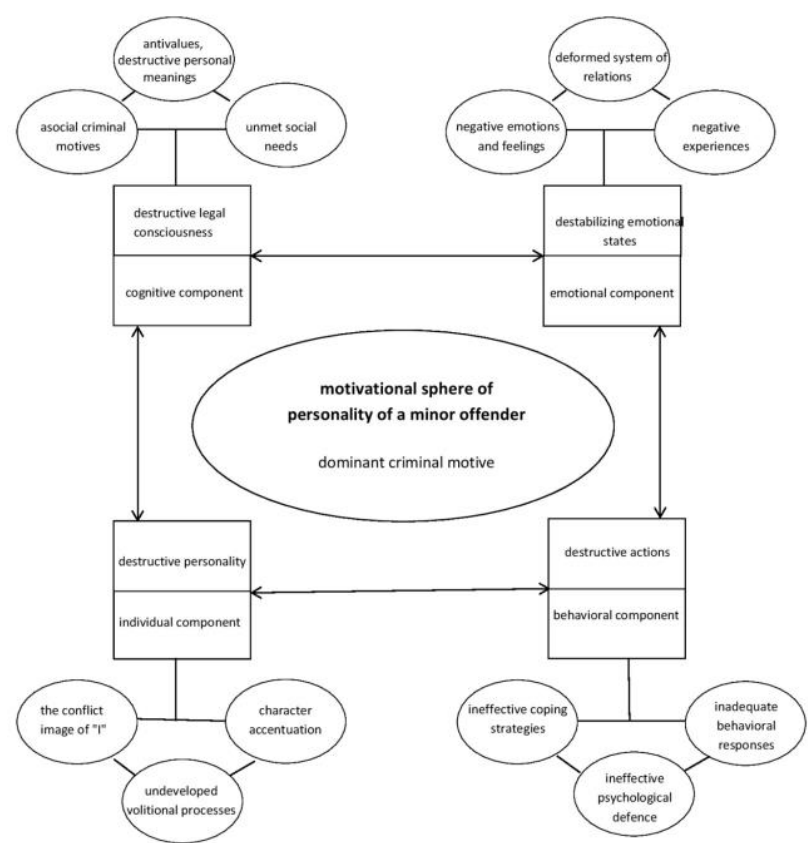

Fig 1: Theoretical model of the structure of the motivational sphere of the personality of a minor offender. 


\section{Discussion}

The conducted research allows to draw the following conclusions. The proposed theoretical model of the motivational structure of the personality of a juvenile offender is constructed taking into account existing scientific concepts and on the basis of the principles of the system-structural approach, the unity of the individual, consciousness and activity, the unity of theory, experiment and practice. The new approach made it possible to examine the motivational sphere of the personality of a minor offender as a system of interrelated and interdependent components and to identify the basic component and systemforming features in it. It allowed to take into account the differentiated and individual approach to the personality of the minor offender and provided an experimental check of the theoretical model in the course of the experimental study. From these positions, the motivational sphere of the personality of a minor offender is a systemic unity and interaction of the individual, personal, cognitive, emotional and behavioral components. The results of the psycho-correctional program "Quartet" are shown in the table.

Table 1: Results of the psycho-correctional program

\begin{tabular}{|c|c|c|c|}
\hline \multicolumn{2}{|c|}{ Options } & \multirow{2}{*}{$\begin{array}{l}\text { Before } \\
\text { training }\end{array}$} & \multirow{2}{*}{ After training } \\
\hline Criteria & Indicators & & \\
\hline \multirow{4}{*}{$\begin{array}{l}\text { Interpersonal } \\
\text { relationships }\end{array}$} & Tension & $47,2 \pm 2,1$ & $45,6 \pm 3,2$ \\
\hline & Alienation & $50,83 \pm 6,1$ & $\begin{array}{l}44,3 \pm 5,2, \\
\text { when } t \leq 0,05\end{array}$ \\
\hline & Conflict & $52,41 \pm 5,9$ & $\begin{array}{l}47,3 \pm 3,61, \\
\text { when } t \leq 0,05\end{array}$ \\
\hline & Aggressiveness & $51,7 \pm 6,3$ & $\begin{array}{l}43,6 \pm 5,5, \\
\text { when } t \leq 0,05\end{array}$ \\
\hline \multirow{7}{*}{$\begin{array}{l}\text { Components of } \\
\text { the structure of } \\
\text { motivation }\end{array}$} & Life support & $16,4 \pm 1,75$ & $16,2 \pm 1,25$ \\
\hline & Comfort & $13,3 \pm 1,2$ & $13,85 \pm 1,75$ \\
\hline & Social status & $13,2 \pm 1,73$ & $14,2 \pm 1,96$ \\
\hline & Communication & $16,5 \pm 1,2$ & $\begin{array}{l}18,24 \pm 1,52 \\
t \leq 0,05\end{array}$ \\
\hline & Public activity & $14,5 \pm 1,95$ & $\begin{array}{l}16,52 \pm 2,3 \\
\text { when } t \leq 0,05\end{array}$ \\
\hline & Creative activity & $14,7 \pm 1,2$ & $18,3 \pm 4,48$ \\
\hline & Social utility & $16,8 \pm 2,82$ & $\begin{array}{l}19,2 \pm 2,86 \\
\text { when } t \leq 0,05\end{array}$ \\
\hline \multirow[t]{3}{*}{ Feelings } & Hedonic & $56,35 \pm 3,2$ & $\begin{array}{l}51,6 \pm 3,23 \\
\text { when } t \leq 0,05\end{array}$ \\
\hline & Asthenic & $48,4 \pm 2,2$ & $\begin{array}{l}43,5 \pm 2,1 \\
\text { when } t \leq 0,05\end{array}$ \\
\hline & Melancholic & $39,27 \pm 2,8$ & $\begin{array}{l}37,05 \pm 3,2 \\
\text { when } t \leq 0,05\end{array}$ \\
\hline
\end{tabular}

The measurements in the control group were compared.

In the experimental group, positive changes of indicator in the criterion "Value orientations".

After the exercises directed at the formation of adequate value systems and the legal awareness of adolescents and young people, as a result of repeated diagnostics, there has been a definite trend in changing priority value systems, for example, the majority of minors did not primarily rank material values, they placed them at the center of ranks, the happiness of other people, which was at the very end of the value orientations of the offenders, was also moved to the fore.

All this shows that after the lessons, the offenders began to think about other people, about their interaction with others, about the fact that they can bring certain benefits, not only harm (as they believed) to others. The changes of average indicators happened inaccordance to the indicators in the criterion "Interpersonal relations". There is a decline of mean values on such parameters as tension, alienation and conflict. It should be noted that there have been relatively minor changes in the tension parameter, perhaps because the offenders have not yet decided on many issues, they have many unresolved problems. On theparameter "aggression", a decrease of average values was observed. This decrease, in our opinion, is the resultof the fact that it appeared that the juvenile has an opportunity to express the self-expression in certain activities, some exercises helped to relax, relieve tension, reduce the level of aggressiveness, increase self-esteem and create positive emotions. Especially the expression of aggression, and then its decline were during the "African dance", where the interaction between participants in the dance process takes place, and they express their actions by shouting, noise, etc. Subsequently, they were explained that they can reduce their negative emotional state, but within the limits of the norm, and without seeking the help of other people around them. It should be noted that increased attention to the personality of the adolescent, to his interests, needs, manifestation of his behavior, clarification of the causes, and the emergence of precisely this form of behavior, led to the appearance of confidence between the participants.

There were also changes in the indicators in the criteria "Components of the structure of motivation", the dominant were communication, social and creative activity. As a result of interpersonal interaction with the leader of the training, with their peers, the adolescents analyzed their actions, and outlined other priority areas of creating the relationship with the society.

There were changes in the indicators of "Feeling", the average value of the parameters of hedonic feelings and asthenic feelings changed. Hedonic feelings before correctional work had high mean values, it was connected with selfish needs, and after classes, many minors revised their behavior and their attitude to life. Based on the listed parameters, significant differences were found. Changes in the average indicators happened in accordance to the indicators "Interpersonal relations" on such parameters as tension, alienation and conflict.

On the parameter"aggression", a decline of mean values is observed. From our point of view, it became possible to express self-expression in certain types of activities. Exercises helped to relieve tension, reduce aggressiveness, increase self-esteem and create positive emotions (due to relaxation, "African dance").

There were also changes in the indicators "Components of the structure of motivation", the dominant elements were communication, social activity and creative activity.

Thus, it can be noted that there has been a positive trend towards a change of the criminal behavior of minors, but at the same time it is necessary to exert psychological influence on all components of criminal motivation.

A control group in which a training program was not conducted was also studied, no significant differences were found. The cognitive component (distorted notions about life values, vital meanings, the purposes of life). It forms a destructive legal consciousness of offenders.

The individual-personality component includes self-awareness, personal senses, accentuated character traits, volitional processes. Due to defects in family upbringing, virtually all deviant adolescents are accentuated personalities, and their volitional processes are very poorly developed, and it creates the basis for the formation of a destructive personality. The behavioral component is represented by such components as coping strategies, reactions, mechanisms of psychological defense (negation, projection, rationalization, substitution compensation, hypercompensation). We can note that offenders have inadequate behavioral reactions.

The emotional component includes emotions, feelings, attitudes and emotional experiences. Constant psycho-traumatic situations, stresses, conflicts, blocking of actual needs, etc. lead to the dominance of negative emotional experiences and emotional imbalance.

In this form, the emotional block creates destructive emotional states of offenders.

Consequently, in cases of criminal motivation, the interaction of destructive personality, destructive legal consciousness, destabilizing emotional states and destructive actions of juvenile offenders arises.

On the basis of the correlation analysis, it was confirmed that the 
motivational sphere is an integral formation, the components of which are interrelated and interdependent. According to the number of relationships found, the basic component is the individual component. System-forming features of this component are the needs for material goods, self-affirmation and recognition, social status. System-forming features of the cognitive component are immoral motive, offense. Behavioral component includes tension, alienation andsystem-forming features of the emotional component are hedonic, melancholic feelings.

In the structure of the motivational sphere of the personality of a minor offender psychological content (needs for comfort, social status and affect, antivalues, intolerance, irreconcilability, aggression, resentment, lack of feel of guilt, low self-control) and the presence of criminal motives (frustration, self-affirmation, emotional, immoral) are connected. The presence of a specific psychological content (rapists have physical aggression, suspicion, insubordination, compensatory behavior, the mercenary offenders have the need for material comfort and comfort, confidence, discipline, rigidity, verbal aggression, mercenary-violent offenders have the need for material goods, resentment, irritability, anxiety, tension, physical and verbal aggression)is specific and depends on the composition of the crime.The offenders have certain hierarchy of criminal motives (rapists - aggressive and frustrating motive, mercenary offenders - self-affirmation, immoral, frustrating, gambling, and mercenary-violent offenders immoral).

Common factors ofoffenders and minors with legitimate behavior that are determined by age characteristics are the need for life support, excitability, cyclothymia, pedantry, irritability, hypertension, emotionality, asthenic feelings. Specific factors of law-abiding minors are the values of the family, happiness, friendship, life-meaning, will, sensitivity; presence, search, rationalization in psychological defense, the ability to sublimate their behavior, their needs; emotional relationship.

Juvenile offenders are dominated by anti-values; destructive meanings; lack of purpose in life; immoral motives; lack of selfcontrol, estrangement. Destructive personality, destructive legal consciousness, destabilizing emotional states and destructive actions lead to criminal behavior.

Factors triggering the formation of the motivational sphere of juvenile offenders are unsatisfied, and hypertrophied material and social needs (needs in self-affirmation, recognition, security). Unfortunately, they cannot meet these needs in socially approved ways. Frustration of the need for acceptance and recognition, friends, activity, independence; alienation, intransigence, tension, are accompanied by game motivation, hypercompensation, ineffective coping strategies and destructive mechanisms of psychological defense.

The immoral motive in the behavioral factor has the greatest meaning, that's why all other parameters are mediated by antisocial motivation. The development of juvenile offenders, the manifestation of their rationality, diligence, accuracy, a sense of duty are aimed at the implementation of immoral acts. They are not connected with work and they are contrary to the happiness of other people.

Juvenile offenders are characterized by a high level of requests. Their actions are often caused by emotional motives based on illbred, aggressive and unbalanced feelings (from pleasure to melancholy and asthenia). Hence they have reactive, spontaneous, irrational character.

Thus, the developed system of prevention and correction of criminal behavior of minors has all the characteristics of the system: integrity, structure, dynamism, hierarchy, stability and openness. It is characterized by a comprehensive approach to content and organization, which is expressed in methodological, technological and functional support, comprehensive diagnosis and prevention through working with a teenager and his microsociety.

To confirm the assumption that it is possible to form adequate motivation for minors and prosocial behavior through changing the components of the motivational sphere of the personality of juvenile offenders, a psycho-correctional program "Quartet" was developed and implemented.

The target of the training was the structural components of criminal motivation: cognitive, emotional, individual-personal and behavioral.

The model of the prevention of juvenile delinquency is aimed at the joint activity of all prevention subjects. In the process of the formative experiment it is established that the motivational sphere of the personality can be corrected by means of sociopsychological training by influencing on the psychological content of all components of the structure. Approbation of the social and psychological training "Quartet" confirmed its effectiveness, positive changes on the parameters of the motivational sphere of the personality of the minor offender were noted.

\section{Results (conclusions)}

1. The cognitive component contains antivalues, meaningful orientations; in the emotional component includes feelings, attitudes; the behavioral component contains inefficient coping strategies, inadequate behavioral responses, destructive mechanisms of psychological defense. The leading role in the formation of psychological defense is played by dominant criminal motives. Comparative analysis made it possible to discover the qualitative uniqueness of the factors shaping the motivational sphere of the personality of law-abiding teenagers and juvenile offenders. A law-abiding teenager has value attitudes toward himself, other people, to the meaning of life.

2 . The developed model of general psychological, pedagogical and socio-criminological prevention of juvenile delinquency is aimed at comprehensive preventive work of relapses of all prevention subjects.

3. The author's psycho-correctional program of Y.A. Malyushina corresponds to the methodological requirements and is based on the dialectical unity of the components of the motivational structure of the personality of juvenile offenders, since psychological influence on all four components of the structure was carried out. The analysis of the differences between the parameters of the psychological content of the components of the motivational sphere of the personality of the juvenile offender (individual, personal, cognitive, emotional and behavioral) of the Student's t-test showed that there are reliable positive changes in the structure of the motivational sphere of the personality of the minor offender. In the control group of minors, there was no change, respectively, the hypothesis put forward by us that the motivation for illegal behavior of minors can be corrected by means of socio-psychological training through understanding the psychological content of the components of the structure of the motivational sphere and changing the hierarchy of leading motives was confirmed.

\section{References}

[1] Antonyan Yu.M, Yustickij V.V., Nesovershennoletnie prestupniki s akcentuaciyami haraktera [Juvenile offenders with character accentuations], Moscow, 1993, pp.45-56.

[2] Aseev, V.G. Motivaciya povedeniya i formirovanie lichnosti [Motivation of behavior and the formation of personality], Moscow, 1976 , p. 158 .

[3] Bartol K. Psihologiya kriminal'nogo povedeniya [Psychology of criminal behavior], St. Petersburg, 2004, p.352.

[4] Belicheva S.A. Psihosocial'naya korrekciya i reabilitaciya nesovershennoletnih $\mathrm{s}$ deviantnym povedeniem [Psychosocial correction and rehabilitation of minors with deviant behavior], Nauka Publ., Moscow, 1999.

[5] Blyasova I. YU., Zajceva L.YU, Deviantnoe povedenie nesovershennoletnih i pravovoj nigilizm.Monografija [Deviant behavior of minors and legal nihilism: monography], LAP LAMBERT Academic Publishing, German, 2014. p.291.

[6] Vasil'ev I.A., Motivaciya i kontrol' za dejstviem [Motivation and 
control of the action], publishing house of Moscow State University, Moscow, 1991, p.144.

[7] Vachkov I.V., Skazkoterapiya. Razvitie samosoznaniya cherez psihologicheskuyu skazku [Fairy tale therapy. The development of self-awareness through a psychological tale], Os'- 89 Publ., Moscow, 2007, p.144.

[8] Enikolopov S.N., Zabryanskij G.I., Cimbal E.I., YAkutova M.A., Pravonarushayushchee povedenie nesovershennoletnih: opisanie, ob"yasnenie, protivodejstvie [Offending behavior of minors: description, explanation, reaction], Novaya yusticiya Publ., Moscow, 2005, p.208.

[9] Enikolopov S.N., Agressivnost' kak specificheskaya storona aktivnosti i vozmozhnosti ee issledovaniya na kontingente prestupnikov [Aggressiveness as a specific aspect of activity and the possibility of its investigation on the contingent of criminals], Prosveshchenie Publ., Moscow, 1979, pp. 83-114.

[10] Zmanovskaya E.V., Deviantologiya: psihologiya otklonyayushchegosya povedeniya [Deviantologiya: psychology of deviant behavior], Akademiya Publ., Moscow, 2003, p. 288.

[11] Klejberg YU.A., Yuvenal'naya yuridicheskaya psihologiya [Juvenile legal psychology], Yusticiya Publ., Moscow, 2017, p. 264.

[12] Klejberg YU.A., Psihologiya deviantnogo povedeniya [Psychology of Deviant Behavior], Yurajt Publ., Moscow, 2017, p. 290.

[13] Klejberg YU.A., Praktikum podeviantologii [Practice on deviantology], Rech' Publ., Moscow, 2007, p. 144.

[14] Kondrat, E.N., Profilaktika delinkventnogo povedeniya nesovershennoletnih [Prevention of delinquent behavior of minors], St. Petersburg state university Publ., St. Petersburg, 2006, p.168

[15] Kudryavcev V.N., Kriminal'naya motivaciya [Criminal motivation], Nauka Publ., Moscow, 2009, p. 303.

[16] Kryukova T.L., Adaptaciya metodik, izuchenie sovladayushchego povedeniya Way of Coping Questionnaire (Oprosnik sposobov sovladaniya R. Lazarusai S. Folkmana) [Adaptation of methods, studying coping behavior Way of Coping Questionnaire (Questionnaire of ways of coping with R. Lazarus and S. Falkman)], Psihologicheskaya diagnostika, 2005, No. 3, pp. 57-76.

[17] Luneev V.V., Prestupnost' XX veka: mirovye, regional'nye i rossijskie tendencii [Crime of XX century: world, regional and Russian trends], Volters Kluver Publ., Moscow, 2005, p. 912

[18] V.D. Mendelevich, Psihologiya deviantnogo povedeniya [Psychology of deviant behavior], Rech' Publ., Moscow, 2005.

[19] Motivation science: social and personality perspectives, Ed. by E.T. Higgins, A.W. Kruglianski, Psychology Press, Philadelphia, 2000, p. 454.

[20] Nyutten Z.H., Motivaciya, dejstvie i perspektiva budushchego [Motivation, action and the prospect of the future], Smysl Publ., Moscow, 2004, p. 607.

[21] Ovcharova R.V., Social'no-pedagogicheskaya zapushchennost' detej i podrostkov [Social and educational neglect of children and adolescents], Kurgan State University, Kurgan, 2008, p. 365.

[22] Pavlik

E.M., Osobennostimotivacionnojsferynesovershennoletnihpravonarushitel ej, dis. kand. psihol. nauk [Features of the motivational sphere of juvenile offenders. Extended Abstract of Dr. habil.Thesis], Nacional'nyj universitet vnutrennih del, Har'kov, 2005.

[23] Pastushenya A.N., Kriminogennaya sushchnost' lichnosti prestupnika: metodologiya poznaniya i psihologicheskaya koncepciya [Criminogenic essence of the criminal personality: the methodology of cognition and the psychological concept], Akademiya MVD Respubliki Belarus', Minsk, 1998, p. 314

[24] Pirozhkov V.F., Kriminal'naya psihologiya. Podrostok v usloviyah social'noj izolyacii [Criminal psychology. Teenager in conditions of social isolation], Os'-89 Publ., Moscow, 1998, p.304.

[25] Pristanskaya O.V., Yuckova E.M., Metodika kriminologicheskogo izucheniya pravosoznaniya i obshchestvennogo mneniya o prestupnosti [The method of criminological study of legal awareness and public opinion about crime], Yurist Publ., Moscow, 2005, p. 231.

[26] Safuanov F.S., Vaskeh E.V., Opredelenie motivacii prestupnogo povedeniya nesovershennoletnih $\mathrm{v}$ ugolovnom sudoproizvodstve [Determination of the motivation of criminal behavior of minors in criminal proceedings], Psihologicheskie issledovaniya, No. 5., 2009.

[27] Sitkovskaya O. D., Psihologiya ugolovnoj otvetstvennosti [Psychology of criminal responsibility], Norma Publ., Moscow, 1998 , p. 285

[28] Hekkhauzen H., Motivaciya i deyatel'nost' [Motivation and activity], Piter Publ., St. Petersburg, 2009, p. 860. 